\title{
Antimicrobial Effectiveness of Maleimides on Fungal Strains Isolated from Onychomycosis
}

\author{
Carla Wanderley Gayoso ${ }^{1}$, Edeltrudes de Oliveira Lima ${ }^{2}$, Evandro Leite de Souza ${ }^{2 *}$, Valdir \\ Cechinel Filho ${ }^{3}$, Vinícius Nogueira Trajano ${ }^{2}$, Fillipe de Oliveira Pereira ${ }^{2}$ and Igara Oliveira \\ Lima $^{2}$ \\ ${ }^{1}$ Laboratório de Tecnologia Farmacêutica; Departamento de Ciências Farmacêuticas; Centro de Ciências da \\ Saúde; Universidade Federal da Paraíba; João Pessoa - PB - Brasil. ${ }^{2}$ Laboratório de Micologia; Departamento de \\ Ciências Farmacêuticas; Centro de Ciências da Saúde; Universidade Federal da Paraíba; João Pessoa - PB - \\ Brasil. ${ }^{3}$ Núcleo de Investigações Químico Farmacêuticas; Universidade do Vale do Itajaí; Itajaí - SC - Brasil
}

\begin{abstract}
This study aimed to analyze the effectiveness of maleimides as inhibitors on the growth of fungal strains isolated from onychomycosis by the solid medium diffusion procedure. The results showed a promising antifungical activity of the assayed maleimides with formation of fungal growth inhibition halos oscillating between diameter 10 and 23mm. MIC was $100 \mu \mathrm{g} / \mathrm{mL}$ for 3,4-dichloro-N-phenyl-methyl-maleimide and 3,4-dichloro-N-phenyl-propil-

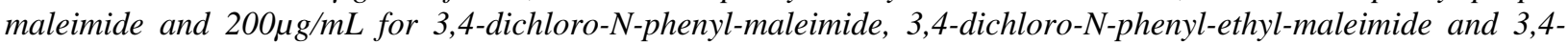
dichloro-N-phenyl-buthyl-maleimide.
\end{abstract}

Key words: Onychomycosis, fungi, maleimides, antifungical activity

\section{INTRODUCTION}

Onychomycosis is a kind of fungal infections in which nails are affected (Sampaio and Rivitti, 1999), more frequently feet nails representing $80 \%$ of the cases (Achten and Wanet-Rouard, 1998). Etiologically, approximately $90 \%$ of the onychomycosis is caused by dermatophyte fungi such as Tricophyton rubrum, T. mentagrophytes var. interdigitale and Epidermophyton flocosum (Graybill, 1992). Yeasts, mainly Candida genera and moulds (e.g. Scytadilium, Acremonium and Cephalosporium) also have been reported as potential onychomycosis agents causing (Juan and Virendra, 2000).

It has been reported that the use of commonly available pharmaceutical preparations applied in onychomycosis treatment have been some times inefficient (Midgley and Moore, 1996), needing to a search for antifungical compounds which would be more effective, cheaper, with wide antifungal spectrum, short time of use and minimum side effects (Juan and Virendra, 2000).

Maleimides are obtained easily and have presented satisfactory profile to the development of new and efficient drugs (Aquino et al., 2003). These have been characterized as similar to the filantimide alkaloid obtained from Phylantus sellowianus of Euphorbiaceae family (Andricopulo et al., 1998). Some compounds inserted in maleimides group showed expressive pharmacological properties as analgesic, anti-spasmodic, antibacterial and antifungical (Cechinel Filho et al., 1994; Santos et al., 1994; Cruz et al., 1996; Corrêa et al., 1997).

\footnotetext{
${ }^{*}$ Author for correspondence
} 
The aim of this study was to evaluate the effectiveness of some maleimides on the growth of fungal strains isolated from onychomycosis.

\section{MATERIALS AND METHODS}

\author{
Maleimides \\ Antifungical action of 3,4-dichloro-N-phenyl- \\ maleimide, 3,4-dichloro-N-phenyl-methyl- \\ maleimide, 3,4-dichloro-N-phenyl-ethyl- \\ maleimide, 3,4-dichloro-N-phenyl-propil- \\ maleimide and 3,4-dichloro-N-phenyl-buthyl- \\ maleimide was analyzed at concentrations of 200 , \\ $100,50,25,12.5,6.3$ and $3.1 \mu \mathrm{g} / \mathrm{mL}$. The solutions \\ were prepared in sterile distillated water prior to \\ assays. Molecular structures of theses are shown in \\ Fig. 1.
}

\section{Fungal strains}

Candida albicans, C. tropicalis, C. krusei, Tricophyton rubrum, $T$. mentagrophytes and Geotrichum candidum strains were used as test microorganisms and obtained from clinical samples collected from patients infected with onychomycosis. Their isolation and identification were carried out according to standard procedures (Rebel and Taplin, 1974; Van-Rij, 1984; Hoog and Guarro, 1995).

\section{Antifungical assay}

Solid medium diffusion procedure using wells in dishes was used to evaluate the antifungical activity (Hadaceck and Greger, 2000). Fungal inoculum of approximately $10^{6} \mathrm{CFU} / \mathrm{mL}$ standardized by McFarland Scale 0.5 tube) and incubation time of 48 hours at $37^{\circ} \mathrm{C}$ for yeasts and $10-14$ days $/ 28^{\circ} \mathrm{C}$ for moulds were used (Pemplel et al., 1986). At the end of the incubation time, the fungal growth inhibition halos diameters were measured in millimeters using calipers. Minimum Inhibitory Concentration - MIC was considered the smallest maleimide concentration able to develop fungal growth inhibition halo equal or higher than 10mm diameter (Lima et al., 1993; Lima et al., 1999). Control assays were performed with ketoconazole $(50 \mu \mathrm{g} / \mathrm{mL})$. All assays were performed twice and the results were expressed as average.

\section{RESULTS AND DISCUSSION}

Infections caused by fungi including those of dermatological interest have shown increasing occurrence since 1980's, which has led to search for alternative substances with efficient antifungical properties and little or no toxicity to host (Graybill, 1992; Hazen, 1995). This high occurrence has been inducing factor for studies regarding the antifungical effectiveness of different chemical compounds on dermatological infections etiological agents (Aquino et al., 2003). The results regarding the sensitivity of fungal strains isolated from onychomycosis to maleimides are shown in Table 1. All assayed fungal strains were sensitive to maleimides, 3,4diclhoro- $N$-phenyl-methyl-maleimide and 3,4diclhoro- $N$-phenyl-propyl-maleimide which showed the smallest MICs. MIC was $200 \mu \mathrm{g} / \mathrm{mL}$ for 3,4-diclhoro- $N$-phenyl-maleimide, 3,4diclhoro- $N$-phenyl-ethyl-maleimide and 3,4 diclhoro- $N$-buthyl-maleimide; and $100 \mu \mathrm{g} / \mathrm{mL}$ for 3,4-diclhoro- $N$-phenyl-methyl-maleimide and 3,4-diclhoro- $N$-phenyl-propyl-maleimide. Fungal growth inhibition halos diameter were between $10 \mathrm{~mm}$ (G. candidum x 3,4-diclhoro- $N$-phenylmethyl-maleimide, G. candidum x 3,4-dicloro- $N$ phenyl-ethyl-maleimide, G. candidum x 3,4diclhoro- $N$-buthyl-maleimide) and $23 \mathrm{~mm}$ ( $T$. mentagrophytes x 3,4-diclhoro- $N$-phenyl-buthylmaleimide).

Resistant behavior in $C$. tropicalis and $T$. mentagrophytes to the standard antifungal (Ketoconazole, $50 \mu \mathrm{g} / \mathrm{mL}$ ) applied as positive control was observed. T. mentagrophytes was the most sensitivity strain with inhibition halos average diameter of $17.2 \mathrm{~mm}$. G. candidum was the least sensitive strain showing inhibition halos average diameter of $10.8 \mathrm{~mm}$.

Lima et al. (1999) found prominent antimicrobial activity in imidic compounds which were effective to inhibit the growth of Escherichia coli, Staphylococcus aureus, Candida albicans, Microsporum canis and Penicillium. Dantas et al. (2000) evaluated the sensitivity of Candida species and dermatophytes to maleimides, naftalimides and succimides and noted that only maleimides showed promising results as Candida inhibitor, while the inhibition of Microsporum and Tricophyton was similar for the three assayed compounds. 


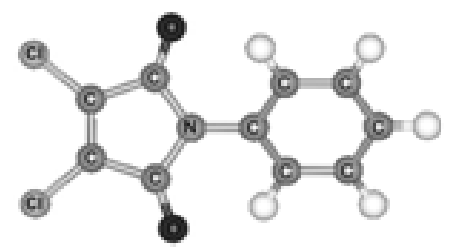

3,4 - diclhoro- $N$-phenyl-maleimide

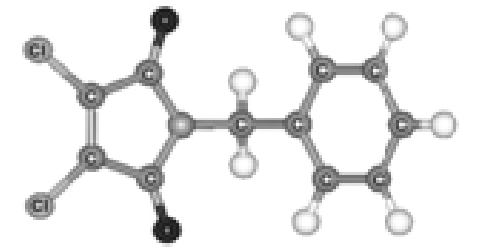

3,4-diclhoro- $N$-phenyl-methyl-maleimide

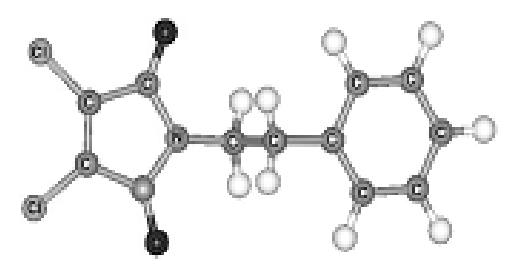

3,4-diclhoro- $N$-phenyl-ethyl-maleimide

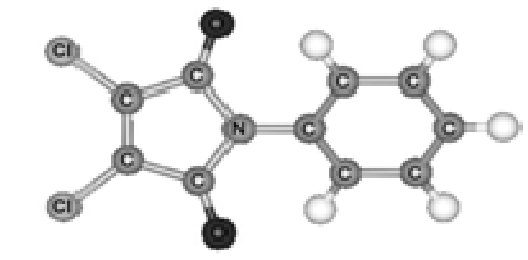

3,4-diclhoro- $N$-phenyl-propyl-maleimide

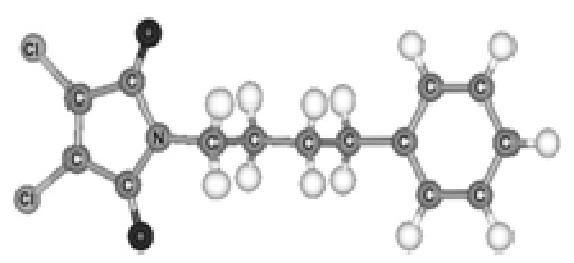

3,4-diclhoro- $N$-phenyl-butyl-maleimide

Figure 1 - Maleimides molecular structure.

Table 1 - Sensitivity of fungal strains isolated from onychomycosis to maleimides as measured in inhibition halos diameter $(\mathrm{mm})$.

\begin{tabular}{|c|c|c|c|c|c|c|}
\hline \multirow[b]{2}{*}{ Maleimides } & \multirow[b]{2}{*}{$M I C^{a}$} & \multicolumn{5}{|c|}{ Fungal strains } \\
\hline & & C. albicans & C. tropicalis & T. rubrum & T. mentagrophytes & G. candidum \\
\hline $\begin{array}{c}\text { 3,4-diclhoro- } N \text { - } \\
\text { phenyl-maleimide }\end{array}$ & 200 & 11 & 16 & 14 & 16 & 11 \\
\hline $\begin{array}{l}\text { 3,4-diclhoro- } N \text { - } \\
\text { phenyl-methyl- } \\
\text { maleimide }\end{array}$ & 100 & 12 & 12 & 16 & 15 & 10 \\
\hline $\begin{array}{c}\text { 3,4-diclhoro- } N \text { - } \\
\text { phenyl-ethyl- } \\
\text { maleimide }\end{array}$ & 200 & 14 & 14 & 12 & 16 & 10 \\
\hline $\begin{array}{l}\text { 3,4-diclhoro- } N \text { - } \\
\text { phenyl-propyl- } \\
\text { maleimide }\end{array}$ & 100 & 17 & 13 & 12 & 16 & 10 \\
\hline $\begin{array}{l}\text { 3,4-diclhoro- } N \text { - } \\
\text { phenyl-butyl- } \\
\text { maleimide }\end{array}$ & 200 & 17 & 13 & 12 & 23 & 13 \\
\hline Ketoconazole $(50 \mu$ & $\mathrm{g} / \mathrm{mL})$ & 22 & $\mathrm{R}$ & 10 & $\mathrm{R}$ & 10 \\
\hline Strain viabililit & & + & + & + & + & + \\
\hline
\end{tabular}

${ }^{\mathrm{a}}$ : expressed in $\mu \mathrm{g} / \mathrm{mL} ;{ }^{\mathrm{b}}$ : fungal growth in Sabouraud agar without adding no maleimide or standard antifungal; R: resistant.

Cechinel Filho et al. (1994) and Cruz et al. (1996) carried out study regarding the antibacterial activity of cyclic amides, including $N$-phenylmaleimides and $N$-aril-diclhoro-maleimides on $S$. aureus, Salmonella tiphymurium and E. coli and reported that only maleimides were able to inhibit these microorganisms presenting MIC between 200 and $50 \mu \mathrm{g} / \mathrm{mL}$. Studies regarding the molecular structure - biological activity relationship of maleimides have showed that their antimicrobial activity possibly could be related with the double bound in the imidic ring or with the nitrogen atom next to the benzene ring, which could lead to electronic interactions between maleimides and microbial cells (Cechinel Filho and Yunes, 1998; Dantas et al., 2000). Moreover, increasing electronic density on nitrogen atom suggests participation in the activation of redox cycles that play major role for development of biological activities (Andricopulo et al., 1998).

The results obtained in our study showed prominent effectiveness of maleimides in inhibiting the growth of onychomycosis etiological agents. These findings and the emergent necessity of developing new and efficient antifungical compounds could lead to a thought regarding the 
possible rational inclusion of these compounds in pharmaceutical compositions used for the antionychomycosis therapy.

\section{RESUMO}

Este estudo objetivou analisar a efetividade de maleimidas como inibidores do crescimento de cepas fúngicas isoladas de onicomicoses através da técnica de difusão em meio sólido. Os resultados mostraram destacável atividade antifúngica das maleimidas ensaiadas com a formação de halos de inibição do crescimento fúngico com diâmetros oscilando entre $10 \mathrm{e}$ $23 \mathrm{~mm}$. A CIM encontrada foi $100 \mu \mathrm{g} / \mathrm{mL}$ para $3,4-$ dicloro- $N$-fenil-metil-maleimida e 3,4-dicloro- $N$ fenil-propil-maleimida e $200 \mu \mathrm{g} / \mathrm{mL}$ para $3,4-$ dicloro- $N$-fenil-maleimida, 3,4-dicloro- $N$-feniletil-maleimida e 3,4-dicloro- $N$-fenil-butilmaleimida.

\section{REFERENCES}

Achten, G. and Wanet-Rouard J. (1998), Onychomycosis in laboratory. Mycosen, 1, 125-129

Andricopulo, A. D.; Willian Filho, A.; Corrêa, R.; Santos, A. R. S.; Nunes, R. J.;Yunes, R. A. and Cechinel Filho, V. (1998), Analgesic activity of 3,4dicloromaleimides: structure activity relationships. Pharmazie, 53, 493-498.

Aquino, P. L. P.; Lima, E. O.; Farias, M. P.; Freire, K. R. L.; Souza, E. L.; Cechinel Filho, V.; Corrêa, R. and Andricopulo, A. (2003), Atividade antifúngica de maleimidas contra dermatófitos isolados de Tinea captis. Rev. Bras. Anal. Clin., 35, 191-194.

Cechinel Filho, V.; Bella Cruz, A.; Nunes, R. J.; Calixto, J. B.; Moretto, E.; Gonzaga, L; Corrêa, R. and Yunes, R. A. (1994), Atividade antimicrobiana de análogos da filantimida. Rev.Latinoamer. Quim,. 23, 116-122.

Cechinel Filho, V. and Yunes, R. A. (1998), Estratégias para a obtenção de compostos farmacologicamente ativos a partir de plantas medicinais, conceitos sobre modificação estrutural para a otimização da atividade. Quim. Nova, 21, 99-105.

Corrêa, R.; Cechinel Filho, V.; Rosa, P. W.; Pereira, C. I.; Schlemper, V. and Nunes, R. J. (1997), Synthesis of new succinimides and sulphonated derivatives with analgesic action in mice. Pharmac. Scien., 3, 67-71.
Cruz, A. B.; Cruz, R. C. B.; Cechinel Filho, V.; Júnior, D. A.; Nunes, R. J. and Yunes, R. A. (1996), Avaliação dos efeitos antibacterianos de $\mathrm{N}$-arildicloromaleimidas e N-arilftalimidas. Relação estrutura-atividade. Rev. Latinoamer. Quim. 25, 10-13.

Dantas, Z. M. R.; Lima, E. O.; Vasconcelos Filho, P. A. and Cechinel Filho, V. (2000), Susceptibilidade in vitro de espécies de Candida a maleimidas, naftalimidas e succinimidas. Rev. Bras. Farm., 81, 31-35.

Graybill, J. R. (1992), Future directions of antifungical chemotherapy. Clin. Infect. Dis., 14, 5170-5181.

Hadacek, F. and Greger, H. (2000), Testing of antifungal natural products: methodologies, comparability of results and essay chosen. Phytochem. Anal., 11, 137-147.

Hazen, K. C. (1995), New and emerging yeast pathogens. Clin. Microbiol. Rev., 8, 462-478.

Hoog, G. S. and Guarro, I. (1995), Atlas of clinical fungi. Central Bureau voor Schimmelcultures/University Rovira I Virgili, Paris.

Juan, S. and Virendra, N.S. (2000), Nail Infections Treatment. Dermatology, 39, 10-14.

Lima, E. O.; Queiroz, E. F.; Andricopulo, A. D.; Yunes, R. A.; Corrêa, R. and Cechinel Filho, V. (1999), Evaluation of antifungal activity of $\mathrm{N}$-arylmaleimides and $N$-phenylalkyl-3,4-dichloromaleimides. Bol. Soc. Chil. Quim., 44, 185-189.

Lima, E. O.; Gompertz, O. F.; Giesbrecht, A. M. and Paulo, M. Q. (1993), In vitro antifungal activity of essential oil obtained from officinal plants against dermatophytes. Mycoses, 36, 333-336.

Midgley, G. and Moore, M. K. (1996), Nail infections. Dermatol. Clin., 14, 41-9.

Pempel, M.; Berg, D.; Buchel, D. B. and Abbink, D. (1986), Test methods for antifungical agents - a critical review. Mykosen. 30, 28-34.

Rebel, G. and Taplin, D. (1974), Dermatophytes their recognition and identification. University of Miami Press, Florida.

Sampaio A. S. and Rivitti, E. A. (1999), Dermatologia. São Paulo: Artes Médicas.

Santos, S. A. R. S.; Cechinel Filho, V.; Niero, R.; Vianna, A. M.; Moreno, I. N.; Campos, M. M.; Yunes, R. A. and Calixto, J. B. (1994), Analgesic effects of callus culture extracts from selected species Phyllanthus in mice. J. Pharm. Pharmacol., 46, 755-759.

Van-Rij, N. I. W. (1984), The yeasts: a taxonomic study. Amsterdam: Elsevier Science Publishers.

Received: February 10, 2005; Revised: September 16, 2005; Accepted: February 03, 2006. 